\title{
NON-SYMBIOTIC NITROGEN FIXATION IN THE RHIZO- SPHERES OF RICE, MAIZE AND DIFFERENT TROPICAL GRASSES
}

\author{
Y. Dommergues, J. Balandreau, G. Rinaudo and Pierrette Weinhard \\ Centre de Pédologie du CNRS, 54, Vandoeuvre-lès-Nancy, France \\ Office de la Recherche Scientifique et Technique Outre-Mer, Dakar, Sénégal
}

(Accepted 1 March 1972)

\begin{abstract}
Summary-Nitrogenase activity estimated in the rhizospheres of rice, maize and different tropical grasses grown under controlled laboratory conditions was shown to depend upon plant species. High nitrogenase activity (2000-6000 nmoles $\mathrm{C}_{2} \mathrm{H}_{4} \mathrm{~h}^{-1} \mathrm{~g}^{-1}$ dry root) occurred in rice rhizosphere, this activity being only 10 times lower than that of symbioticsystems; in the rhizosphere of many other grasses grown in a similar way nitrogenase activity was as low as 10 nmoles $\mathrm{C}_{2} \mathrm{H}_{4} \mathrm{~h}^{-1} \mathrm{~g}^{-1}$ dry root. The influence of soil type on nitrogenase activity was impressive; but the exact nature of the factors implicated could not be established. A rather weak flush of nitrogenase activity in the rhizosphere occurred in the early stage of the plant growth; it was probably due to the exudation of compounds from the seed and lasted 2 or 4 days according to the size of the seed. When the plant entered into its intense photosynthetic phase, the nitrogenase activity gradually increased. When the shoots were severed, nitrogenase activity in the rhizosphere ceased. Nitrogenase activity in the rhizosphere responded greatly to light intensity. Extrapolation of these laboratory findings to the field is discussed.
\end{abstract}

\section{INTRODUCTION}

THE ECOLOGTCAL significance of non-symbiotic nitrogen fixation in the rhizosphere is one of the most controversial problems in the field of soil biology. Some authors, who have studied the role of Azotobacter in the rhizosphere, think that the contribution of this bacterium to nitrogen enrichment is negligible (Mishustin and Shilnikova, 1969). On the other hand, it has been suggested that, at least under tropical climates and in the rhizosphere of some plants, non-symbiotic nitrogen fixation must not be overlooked (Döbereiner, 1968). For $2 \mathrm{yr}$, we have been studying this problem using acetylene reduction assay in the case of laboratory grown plants (Hauke-Pacewiczowa et al., 1970; Rinaudo et al., 1971; Balandreau et al., 1971; Weinhard et al., 1971). This paper presents results from a number of recent experiments in which some major factors affecting nitrogenase activity have been examined in the rhizosphere of various plants.

\section{MATERIALS AND METHODS}

\section{Soils}

Most of the soils used were tropical and were sampled to a depth of approximately $10 \mathrm{~cm}$ (Table 1). 
TABLE 1. Description OF EXPERIMENTAL SOILS

\begin{tabular}{|c|c|c|c|c|c|c|c|}
\hline Soil no. & Soil type & Origin & $\mathrm{pH}$ & $\begin{array}{l}\mathrm{C} \\
(\%)\end{array}$ & $\begin{array}{c}N \\
(\%)\end{array}$ & $\mathrm{C}: \mathrm{N}$ & $\begin{array}{l}\text { Clay } \\
(\%)\end{array}$ \\
\hline 1 & Oxic fluvent & Dabou, Ivory Coast & $4 \cdot 1$ & $4 \cdot 70$ & $0 \cdot 29$ & $16 \cdot 4$ & 63 \\
\hline 2 & Oxic fluvent & Abengourou, Ivory Coast & $4 \cdot 2$ & $3 \cdot 17$ & $0 \cdot 23$ & $13 \cdot 8$ & 29 \\
\hline 3 & Oxic fluvent & Yamoussokro, Ivory Coast & $5 \cdot 8$ & 1.78 & $0 \cdot 15$ & $11 \cdot 8$ & 27 \\
\hline 4 & Oxisol & $\begin{array}{l}\text { Ambatobe, Tananarive, } \\
\text { Madagascar }\end{array}$ & $4 \cdot 2$ & 0.95 & 0.074 & $12 \cdot 8$ & 21 \\
\hline 5 & Ustipsamment & Lamto, Ivory Coast & $6 \cdot 0$ & 0.83 & 0.07 & $11 \cdot 8$ & 5 \\
\hline 6 & Ustipsamment & Bambey, Senegal & $4 \cdot 5$ & $0 \cdot 17$ & 0.014 & $12 \cdot 0$ & 2 \\
\hline 7 & Typic eutrochrept & Pixérécourt, France & $7 \cdot 8$ & $3 \cdot 25$ & $0 \cdot 29$ & $11 \cdot 2$ & 23 \\
\hline
\end{tabular}

NB-After waterlogging, the pH's of soils 1,2 and 3 increased up to $6 \cdot 3,6 \cdot 6$ and $6 \cdot 9$.

\section{Plants}

Plants used were rice (var. IR8), Eleusine coracana, maize (var. INRA 260); Paspalum virgatum, Pennisetum purpureum, Panicum maximum from O.R.S.T.O.M. experimental station at Adiopodoumé (Ivory Coast); Cyperus zollingeri, Cyperus obtusiflorus from Lamto I.B.P. station (Ivory Coast). Rice, maize and Eleusine coracana plants were obtained from seeds, other plants from root-stocks. The plants were cultivated in cabinets under the following conditions: light intensity, 30,000 lux, $16 \mathrm{~h}$ illumination per day; temperature, $28 \pm 2{ }^{\circ} \mathrm{C}$; relative air humidity, $70-90$ per cent. The rice soils were waterlogged and, in the case of Paspalum virgatum, soils were kept at water holding capacity. The other plants were grown in plastic containers placed in jars that were one-half to two-thirds filled with water. For each treatment, there were 5-6 replicates.

\section{Acetylene reduction assays}

The technique was similar to that of Hardy et al. (1968) and Stewart et al. (1967) except that test materials were exposed to a gas mixture containing 90 per cent $\mathrm{Ar}$ and 10 per cent $\mathrm{C}_{2} \mathrm{H}_{2}$, previous experiments having shown that omission of oxygen did not impede $\mathrm{C}_{2} \mathrm{H}_{2}$ reduction (Rinaudo et al., 1971). This technique was used with two systems: (1) 'soil + plant' systems (rhizosphere soils) extracted in one piece from the growth vessels; (2) 'control soil' systems (non-rhizosphere soils), where no plants had been grown. These materials were exposed at $30 \pm 1^{\circ} \mathrm{C}$ to gas mixture, in the dark, for about 4, 7, 20,24 and 30 h. Maximum $\mathrm{C}_{2} \mathrm{H}_{2}$ reduction rates, expressed as nmoles $\mathrm{C}_{2} \mathrm{H}_{4} \mathrm{~h}^{-1} \mathrm{~g}^{-1}$ dry weight of soil or root, were calculated from time-course curves of $\mathrm{C}_{2} \mathrm{H}_{2}$ reduction. The rhizosphere effect was measured as the difference between the activities of 'soil + plant' and of soil alone. The latter was usually negligible. Preliminary experiments showed little difference between tests in which the 'soil + plant' was assayed in the growth containers (Dr. J. Döbereiner, personal communication), or extracted and assayed in one piece as described above.

\section{RESULTS}

Because of the great variability of nitrogenase activity, it is difficult to classify the rhizosphere effects according to plant species. However preliminary results (Table 2) show that these effects in decreasing order are rice $>$ Eleusine coracana, Paspalum virgatum, Cyperus zollingeri and Cyperus obtusiflorus $>$ Panicum purpureum and Panicum maximum. 
TABLE 2. NITROGENASE ACTIVITY IN THE RHIZOSPHERES OF RICE AND DIFFERENT TROPICAL GRASSES

\begin{tabular}{lccc}
\hline \multicolumn{1}{c}{ Plant species } & $\begin{array}{c}\text { Age of plant } \\
\text { (months) }\end{array}$ & $\begin{array}{c}\text { Soil } \\
\text { no. }\end{array}$ & $\begin{array}{c}\text { Nitrogenase activity } \\
\text { (nmoles } \mathrm{C}_{2} \mathrm{H}_{4} \mathrm{~h}^{-1} \mathrm{~g}^{-1} \text { dry root)* }\end{array}$ \\
\hline Rice & $\simeq 1$ & 1 & $1800 \pm 274$ \\
& $\simeq 1$ & 2 & $1190 \pm 140$ \\
& $\simeq 1$ & 3 & $1430 \pm 205$ \\
Eleusine coracana & $\simeq 0 \cdot 3$ & 1 & $6153 \pm 1516 \dagger$ \\
Paspalum virgatum & $\simeq 1$ & 5 & $374 \pm 165$ \\
& 4 & 4 & $1 \cdot 3 \pm 0 \cdot 5$ \\
Pennisetum purpureum & 8 & 4 & $528 \pm 48$ \\
Panicum maximum & 2 & 4 & $345 \pm 163$. \\
Cyperus zollingeri & 2 & 5 & $4 \pm 0 \cdot 7$ \\
& 3 & 5 & $10 \pm 1 \cdot 1$ \\
Cyperus obtusiflorus & 6 & 5 & $110 \pm 25$ \\
& 6 & 5 & $352 \pm 66$ \\
\hline
\end{tabular}

* \pm Standard deviation.

$\dagger$ Maximum value from Fig. 3.

When nitrogenase activity was expressed on a root weight basis, time curves, for seedlings growing at 30,000 lux, showed two stages: (1) stage of increase of activity which lasted 5-10 days, (2) stage of stabilization (Fig. 1) or decrease (Fig. 3). At 3000 lux, a flush of nitrogenase activity occurred during the early stage (Fig. 2). When nitrogenase activity was expressed on a soil weight basis, time curves, for seedlings growing at 30,000 lux, showed increasing activity throughout the experiment except for a short interval (Fig. 1).

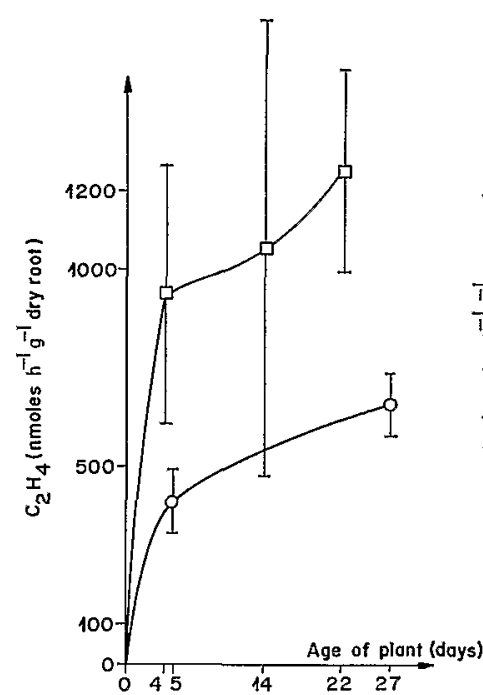

(a)

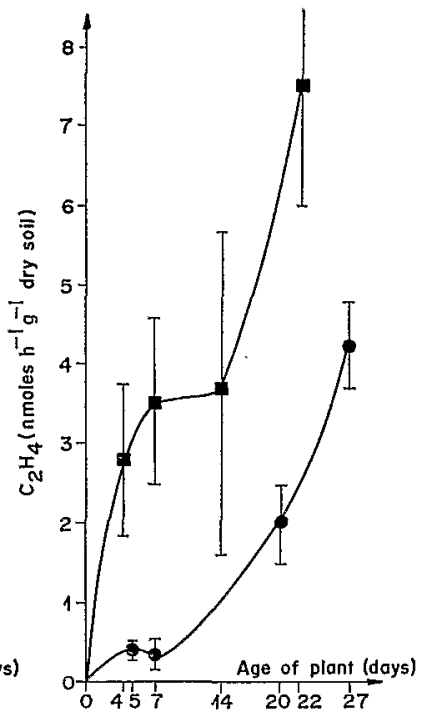

(b)

FIG. 1(a). Time course of nitrogenase activity (per $\mathrm{g}$ dry root) in the rhizospheres of rice $(\mathrm{O}-\mathrm{O}$ ) or maize $(\square-\square)$ seedlings grown at 30,000 lux in soil 7. (b) Time course of nitrogenase activity (per $\mathrm{g}$ dry soil) in the same rhizospheres of rice (-C) and maize (1. ) seedlings grown in the same conditions. Limits show standard error of means. 


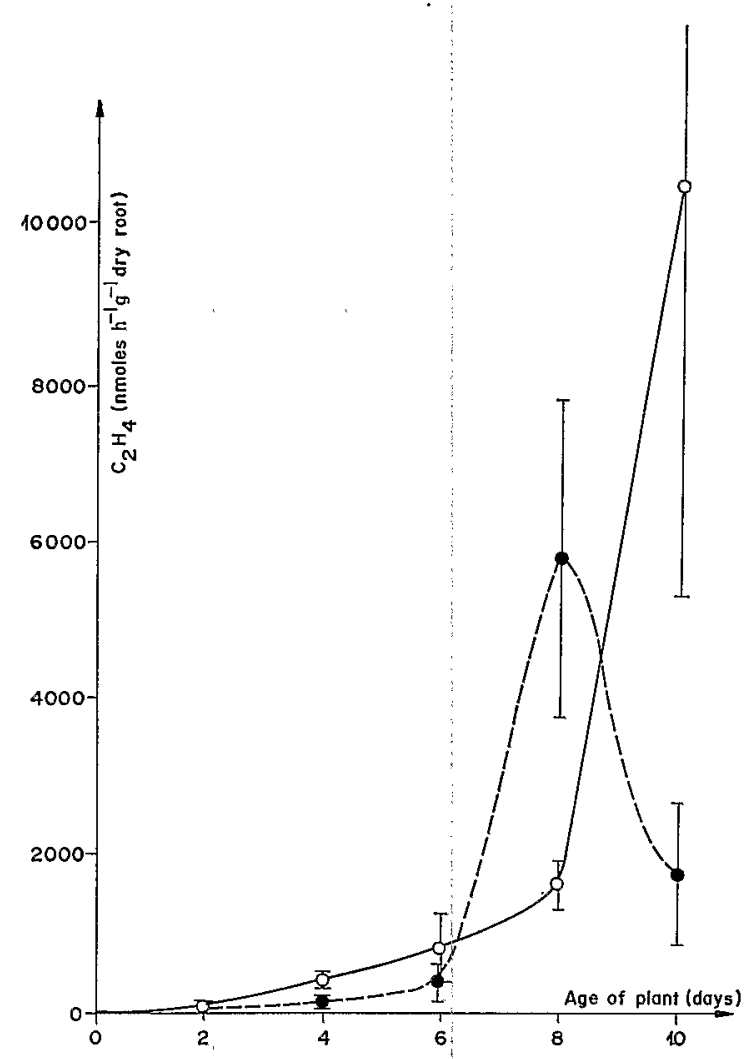

FIg. 2. Time course of nitrogenase activity (per $g$ dry root) in the rhizosphere of young maize seedlings grown at 30,000 lux $(\mathrm{O}-\mathrm{O})$ and at $3000 \operatorname{lux}(\mathbf{0 - 0})$ in soil 7 . The flush which occurs at the 8 th day is probably induced by root exudates supplied by seed reserves. Limits show standard ertor of means.

The influence of soil type on nitrogenase activity could be considerable; for instance in the case of Eleusine coracana, this activity was 100 times greater in soil 5 than in soil 6 (Table 2).

Rice seedlings were grown under normal light (30,000 lux) during a 10-day period, after which half of them were shaded, thus reducing the light to about 3000 lux. Time-curves of nitrogenase activity expressed on a root weight basis showed that within $24 \mathrm{~h}$, shading had reduced nitrogenase activity to one-sixth of the unshaded value (Fig. 3).

When shoots of rice grown in soil 1 were severed, nitrogenase activity in the rhizosphere decreased sharply (Fig. 4). Within 5 days from cutting, nitrogenase activity expressed on a soil weight basis was negligible. Identical results had been obtained previously with rice grown in the same conditions in soils 2 and 3 (Rinaudo, 1970).

\section{DISCUSSION AND CONCLUSION}

\section{Evidence of nitrogenase activity in the rhizosphere}

Nitrogenase activity could be demonstrated in the rhizosphere of most of the plants we studied. This activity was rather low in some cases, but in the case of rice it reached values as high as 2000 or 6000 nmoles $\mathrm{C}_{2} \mathrm{H}_{4} \mathrm{~h}^{-1} \mathrm{~g}^{-1}$ root (dry weight). Compared with results 


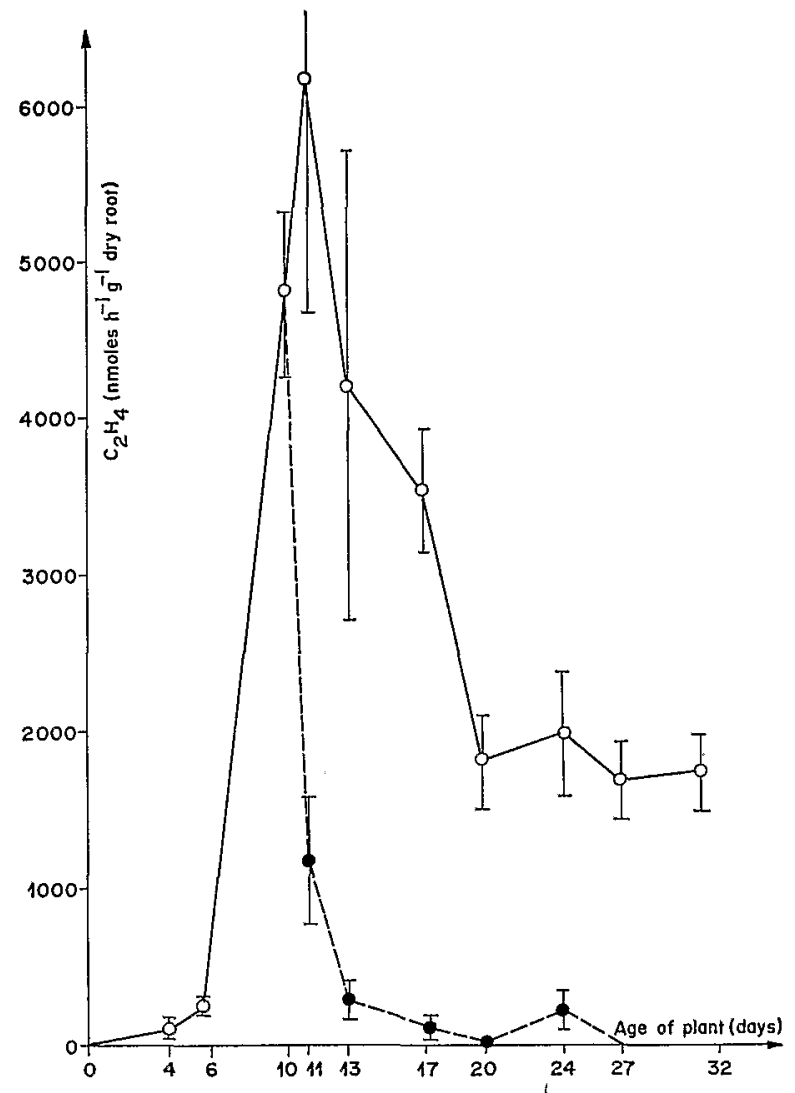

FIG. 3. Time course of nitrogenase activity (per $g$ dry root) in the rhizosphere of rice seedlings grown in soil 1 at 30,000 lux $(\mathrm{O}-\mathrm{O})$. The line $(0--\infty)$ represents the time course of nitrogenase activity in the rhizosphere after the seedlings had been shaded (3000 lux). Limits show standard error of means.

obtained by Yoshida and Ancajas (1970) and Döbereiner et al. (1971), the latter figures seem abnormally high. In our experiments the soils may have been contaminated by nitrogenfixing algae; but this objection cannot stand, because the $\mathrm{C}_{2} \mathrm{H}_{2}$ assays were carried out in the dark and $\mathrm{C}_{2} \mathrm{H}_{2}$ reduction-did not decrease with time. Moreover non-rhizosphere soil controls always showed very low nitrogenase activity.

It is interesting to compare nitrogenase activities of efficient non-symbiotic nitrogenfixing systems (such as rice rhizospheres) with those of well-known symbiotic nitrogenfixing systems (i.e. legume or non-legume nodules); in the former nitrogenase activity can reach 1000-6000 nmoles $\mathrm{C}_{2} \mathrm{H}_{4} \mathrm{~h}^{-1} \mathrm{~g}^{-1}$ dry root, in the latter, 10,000-80,000 nmoles $\mathrm{C}_{2} \mathrm{H}_{4}$ $\mathrm{h}^{-1} \mathrm{~g}^{-1}$ dry nodule (Hardy et al., 1968; Wheeler, 1969; Schwinghamer et al., 1970; Döbereiner et al., 1971). Expressed on a root weight basis, nitrogenase activity in efficient nonsymbiotic systems was thus about one-tenth of that of symbiotic systems (Weinhard et al., 1971).

Factors affecting nitrogenase activity in the rhizosphere

Since the microflora on and around the roots is dependent very largely for its supply of organic nutrients on exudation from the roots (Rovira, 1965), it was predictable that 


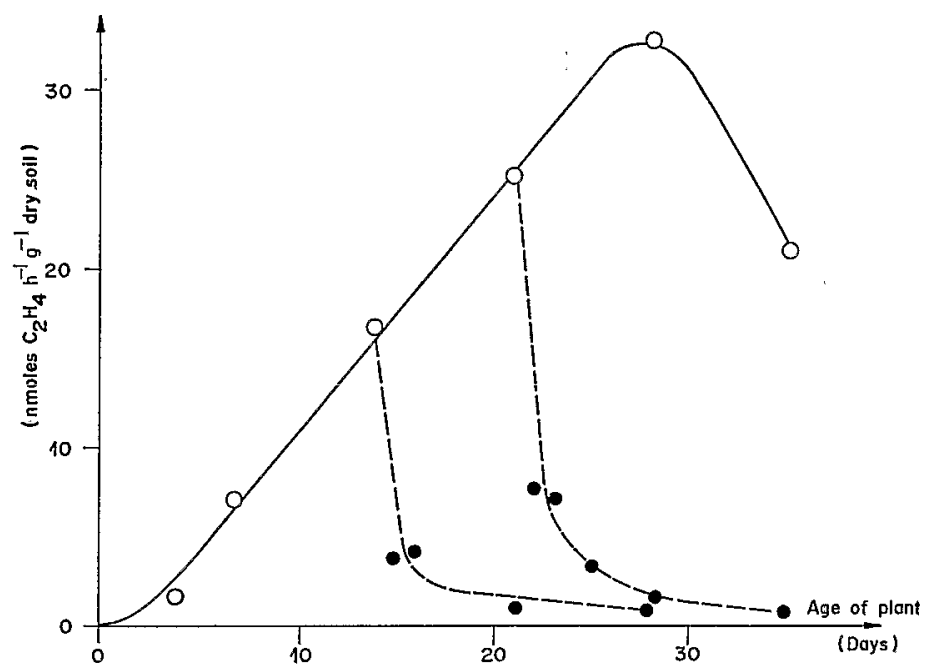

FIG. 4. Time course of nitrogenase activity (per $\mathrm{g}$ dry soil) in the rhizosphere of intact rice seedlings $(\mathrm{O}-\mathrm{O})$ and in the rhizosphere of decapitated rice seedlings $(---\infty)$ grown in soil 1. Stems were severed when seedlings were 14 or 21 days old.

factors controlling exudation would also control nitrogenase activity. Our experiments have confirmed this assumption.

Some plants species, especially rice, induced a very favorable environment; on the contrary, others, such as Pennisetum purpureum or Panicum maximum, were much less favourable for nitrogenase activity in the rhizosphere.

During the first stages of growth, time-curves of nitrogenase activity in the rhizosphere of seedlings appeared to depend on light intensity. In the case of well-lit seedlings (30,000 lux) nitrogenase activity expressed on a root weight basis, increased progressively with age. In the case of shaded seedlings ( $3000 \mathrm{lux}$ ), this activity occurred as a flush followed by a sharp decrease. As this flush was not light-dependent, presumably it was induced by root exudates supplied by seed reserves (Balandreau et al., 1971). When plants were older (more than 10-20 days in our experiments), nitrogenase activity, estimated on a root weight basis, decreased. Thus in the older parts of rhizospheres, nitrogenase activity would probably be less than in younger regions.

Light intensity, by affecting the photosynthetic process, is known to influence the qualitative and quantitative nature of root exudates (Rovira, 1965; Barber, 1969). This fact explains that shading caused a dramatic decrease of nitrogenase activity within $24 \mathrm{~h}$; it also explains how shoot removal similarly reduced this activity within a few days.

The influence of soil type on nitrogenase activity in the rhizosphere is considerable, but we do not yet know the exact nature of the factors implicated. Are they biological, physical or purely chemical? Oxygen deficiency is a most important factor (cf. Hauke-Pacewiczowa et al., 1970), but other factors such as phosphorus and organic matter content, must not be overlooked.

\section{Validity of the acetylene reduction assay}

The use of the acetylene reduction assay for estimation of nitrogen-fixing activity implies that the quantity of acetylene reduced is directly related to the amount of nitrogen that could have been reduced. One might expect that, since 6 electrons are required for the reduction 
of a nitrogen molecule and 2 for an acetylene molecule, the ratio ' $\mathrm{C}_{2} \mathrm{H}_{2}: \mathrm{N}_{2}$ ' would be $3: 1$. But it has been shown that, in number of living systems, this ratio could be different from this theoretical value (Bergersen, 1970; Dr. M. J. Dilworth, personal communication). That is why Bergersen (1970) emphasized the necessity of establishing a calibration for this relationship for every system studied. This calibration in the case of rice rhizosphere has given values close to 3 (Rinaudo and Dommergues, 1971). We have assumed that this value would also be characteristic of rhizospheres of other plants, but this assumption will have to be corroborated.

\section{Extrapolation of laboratory measures to the field}

Results obtained in controlled environment cabinets cannot be extrapolated to the field without taking into account (1) in situ climatic and edaphic conditions (2) the quantity of really active roots. Our knowledge of the ecology of nitrogen-fixing organisms is still not sufficient to allow us to make these corrections. The best way to solve the problem would be to use in situ methods to estimate nitrogenase activity. Results of preliminary laboratory experiments suggest that maximum biological nitrogen-inputs are to be found in ecosystems with the following features: waterlogged soil, sunny climate, and root systems that form large amounts of exudates. Rice fields possess these features.

\section{REFERENCES}

Balandreau J., Weinhard P., Rinaudo G. and Dommergues Y. (1971) Influence de l'intensité de l'éclairement de la plante sur la fixation non symbiotique d'azote dans la rhizosphère. Oecol. Plant. 6, 341-351.

BARber D. A. (1969) The influence of the microflora on the accumulation of ions by plants. In Ecological Aspects of the Mineral Nutrition of Plants. (I. H. Rorison, Ed.): Sym. Br. ecol. Soc. 9, 191-200.

Bergersen F. J. (1970) The quantitative relationship between nitrogen fixation and the acetylene-reduction assay. Aust. J. biol. Sci. 23, 1015-1026.

Döbereiner J. (1968) Non-symbiotic nitrogen fixation in tropical soils. Pesq. agropec. Bras. 3, 1-6.

Döbereiner J., DAY J. and DART P. J. (1971) Nitrogenase activity of the Paspalum notatum-Azotobacter paspali association and oxygen sensitivity. $J$. gen. Microbiol. In press.

Hardy R. W. F., Holsten R. D., Jackson E. K. and Burns R. C. (1968) The acetylene-ethylene assay for $\mathrm{N}_{2}$ fixation: laboratory and field evaluation. Pl. Physiol. 43, 1185-1207.

Hauke-Pacewiczowa T., Balandreau J. and Dommergues Y. (1970) Influence de l'engorgement sur la fixation microbienne de l'azote moléculaire dans la rhizosphère du mais. C.r. hebd. Acad. Sci. Paris 269, 1356-1358.

Mishustin E. N. and Shrmnikova V. K. (1969) The biological fixation of atmospheric nitrogen by free-living bacteria. In Soil Biology, 65-124, Unesco, Paris.

RiNaumo G. (1970) Fixation biologique de l'azote dans trois types de sols de rizières de Côte d'Ivoire. Thèse Doctorat Ing. Fac. Sci. Montpellier, p. 121.

Rinaudo G. and Dommergues Y. (1971) Validité de l'estimation de la fixation biologique de l'azote dans la rhizosphère par la méthode de réduction de l'acétylène. Ann. Inst. Pasteur 121, 93-99.

Rinaudo G., Balandreau J. and Dommergues Y. (1971) Algal and bacterial non-symbiotic nitrogen fixation in paddy soils. Pl. Soil. Spec. Vol., 471-479.

Rovira A. D. (1965) Interactions between plant roots and soil microorganisms. Ann. Rev. Microbiol. 19, 241-256.

Schwrnghamer E. A., Evans H. J. and Dawson M. D. (1970) Evaluation of effectiveness in mutant strains of Rhizobium by acetylene reduction relative to other criteria of $\mathrm{N}_{2}$ fixation. Pl. Soil. 33, 192-212.

Stewart W. D. P., FitzGerald G. P. and Burris R. H. (1967) In situ studies on nitrogen fixation using the acetylene reduction technique. Proc. natn. Acad. Sci. USA 58, 2071-2078.

Weinhard P., Balandreau J., Rinaudo G. and Dommergues Y. (1971) Fixation non symbiotique de l'azote dans la thizosphère de quelques non-légumineuses tropicales. Rev. ecol. Biol. Sol. 8, 367-373.

WheELER C. T. (1969) The diurnal fluctuations in nitrogen fixation in the nodules of Alnus glutinosa and Myrica gale. New Phytol. 68, 675-682.

Yoshida T. and Ancajas R. R. (1970) Application of the acetylene reduction method in nitrogen fixation studies. Soil sci. Pl. Nutr. 16, 238-244. 